Original article

\title{
Gender differences in cumulative life-course socioeconomic position and social mobility in relation to new onset diabetes in adults - the Brazilian Longitudinal Study of Adult Health (ELSA-Brasil)
}

\author{
Lidyane V. Camelo PhD ${ }^{\mathrm{a}}$, Luana Giatti PhD ${ }^{\mathrm{a}}$, Bruce B. Duncan PhD ${ }^{\mathrm{b}}$, Dóra Chor $\mathrm{PhD}^{\mathrm{c}}$, \\ Rosane Härter Griep $\mathrm{PhD}^{\mathrm{d}}$, Maria Inês Schmidt $\mathrm{PhD}^{\mathrm{b}}$, Sandhi Maria Barreto $\mathrm{PhD}^{\mathrm{a}, *}$ \\ ${ }^{a}$ Postgraduate Program in Public Health, Faculty of Medicine, Universidade Federal de Minas Gerais, Belo Horizonte, Brazil \\ ${ }^{\mathrm{b}}$ Postgraduate Program in Epidemiology and Hospital de Clinicas de Porto Alegre, Universidade Federal Rio Grande do Sul, Porto Alegre, Brazil \\ ${ }^{\mathrm{c}}$ Escola Nacional de Saúde Pública, Fundação Oswaldo Cruz, Rio de Janeiro, Brazil \\ ${ }^{\mathrm{d}}$ Laboratory of Health and Environment Education, Fundação Oswaldo Cruz, Rio de Janeiro, Brazil
}

\section{A R T I C L E I N F O}

\section{Article history:}

Received 16 May 2016

Accepted 28 September 2016

Available online 8 October 2016

\section{Keywords:}

Life-course epidemiology

Diabetes

Health inequalities

Social mobility

\begin{abstract}
A B S T R A C T
Purpose: We investigated gender-specific associations of cumulative socioeconomic position across life course and social mobility with new onset diabetes mellitus (NODM) in over 12,000 civil servants in Brazil.

Methods: We used data from ELSA-Brasil baseline (2008-2010). The accumulation of risk was assessed using an education-based score and an occupation-based score. Educational and occupational social mobility were also evaluated.

Results: In minimally adjusted models, NODM increased with increasing exposure to life-course social disadvantages, especially in men. This gender difference was pronounced when cumulative processes were evaluated by education-based scores (high vs. low cumulative social disadvantage, odds ratio $[\mathrm{OR}]=4.7 ; 95 \%$ confidence interval $[\mathrm{CI}]: 2.6-8.5$ in men and $\mathrm{OR}=2.0 ; 95 \% \mathrm{CI}$ : $1.1-3.6$ in women). After including proximal diabetes risk factors possibly acting as mediators, these associations remained high only in men (high vs. low cumulative social disadvantage, $\mathrm{OR}=4.4 ; 95 \% \mathrm{CI}: 2.4-8.1$ ). Social mobility was associated with NODM in men. Compared to the high-stable trajectory, downward had greater associations than upward mobility. In women, when considering metabolic syndrome-related variables, changes in social hierarchy did not seem to have an influence on their risk of diabetes.

Conclusions: Accumulation of risk and social mobility were associated with NODM with gender-specific patterns, suggesting differences in mechanisms connecting life-course socioeconomic position and diabetes in men and women.
\end{abstract}

(c) 2016 Elsevier Inc. All rights reserved.

\section{Introduction}

Diabetes is the seventh highest cause of global disease burden when evaluating by years of life lived with disability [1], and this burden disproportionately affects people in adverse socioeconomic position (SEP) [2]. Evidence has also been accumulating that exposure to social adversities early in life plays a role in promoting

\footnotetext{
* Corresponding author. Projeto ELSA, Hospital Borges da Costa, Universidade Federal de Minas Gerais, Avenida Professor Alfredo Balena, 190, Belo Horizonte, Minas Gerais 30130-100, Brazil. Tel./fax: +55-31-3409-9140.

E-mail address: sbarreto@medicina.ufmg.br (S.M. Barreto).
}

insulin resistance [3], incidence of diabetes [4-5], and diabetesrelated mortality [6]. The number and duration of social adversities, throughout one's lifetime, have also been associated with diabetes in a dose-response manner [4,7-9]. This finding supports the accumulation risk model, a theoretical causal framework that advocates the total exposure to social adversities across one's lifespan is a determinant of risk for the disease [10]. Moreover, increased diabetes risks have been observed in individuals who have descended the social hierarchy [4,5,11-13], corroborating the social mobility model, which postulates that the trajectories across social structures during one's lifetime might be determinants of disease risk [14]. 
Previous studies also reported the existence of gender differences in the association of social mobility and cumulative SEP with diabetes, with stronger and more consistent associations observed in women [9,11-13]. However, an absence of gender differences has also been reported [4]. The causes for gender differences in these associations have not been explored at length and might reflect differences in mechanisms connecting life-course SEP and diabetes in men and women.

Most studies that looked at the role of risk accumulation and social mobility in relation to diabetes were carried out in highincome countries. However, exposure to socioeconomic adversities throughout life tends to be more pronounced in low- and middle-income nations, and social mobility tends to be lower in unequal countries [15]. For example, the illiteracy rate in Brazil was $56 \%$ in the 1940 [16], and although it decreased to 8\% in 2013 [17], it was still greater than the illiteracy rate of $3 \%$ observed in the United States and in France in 1940 [16]. Additionally, inequality and poverty levels have sharply decreased over the past few years in Brazil and a notable fraction of the population has experienced a recent upward socioeconomic mobility [18]. However, Brazil remains one of the countries with the highest income inequalities in the world. According to the Organization for Economic Cooperation and Development, the gap between the rich and the poor is about five times higher in Brazil than in the Organization for Economic Cooperation and Development countries [19]. Moreover, international comparisons also place Brazil as one of the countries with the lowest intergenerational social mobility $[15,20]$.

We aimed to investigate gender-specific associations of cumulative SEP throughout life course and social mobility with new onset diabetes mellitus (NODM) in middle-aged civil servants born between 1934 and 1975 in Brazil.

\section{Methods}

This study used baseline data (2008-2010) of the Brazilian Longitudinal Study of Adult Health (ELSA-Brasil), a multicenter cohort study of 15,105 civil servants, aged 35 to 74 years, and enrolled in universities or research institutions located in six Brazilian capitals (Belo Horizonte, Porto Alegre, Rio de Janeiro, Salvador, Sao Paulo, Vitoria). ELSA-Brasil includes volunteers (76\%) and actively recruited participants (24\%), the latter being recruited from a random list of employees, stratified by sex, age, and occupation. The ELSA-Brasil cohort includes a wide range of positions and/or jobs and salaries that vary according to the level of education/training required. For instance, the cohort includes professors and researchers; clerks; secretaries and other office workers; nurses (registered, assistant, and licensed practical); medical and laboratory technicians; and installation, maintenance, and repair workers. Participants were recruited through onsite and radio announcements, mail, outdoor billboards, and telephone calls. Efforts were made to recruit similar proportions of men and women as well as predefined proportions of age groups and occupational categories. The baseline examination consisted of interviews, clinical, laboratory, and anthropometric examinations at the study clinics [21,22]. The ethics committee of each institution approved the research protocol, and volunteers gave written consent to participate.

For this investigation, we excluded 1473 individuals previously diagnosed with diabetes (self-reported medical diagnosis of diabetes or self-reported use of medication for diabetes) and participants with missing information on their diabetes status $(n=3)$. From the 13,629 eligible participants, we also excluded individuals with missing data on any of the variables included in the analysis, as summarized in Table 1. Thus, our final samples for analysis using education and occupation indicators comprised 12,960, and 12,415 participants, respectively.

\section{Study variables}

\section{New onset diabetes mellitus}

After 12 hours of fasting, a blood sample was drawn by venipuncture shortly after each participant arrived at the baseline clinic. A 2-hour oral-glucose-tolerance test of $75 \mathrm{~g}$ was administered to participants without known diabetes. Glucose was measured by the hexokinase method (ADVIA Chemistry; Siemens, Deerfield, Illinois). Glycated hemoglobin was measured using high-pressure liquid chromatography (Bio-Rad Laboratories, Hercules, California).

NODM was defined according to blood glucose measurements. Specifically, a participant was defined as having NODM if he and/or she did not report previous diagnoses of diabetes or use medication for diabetes and met at least one of the following conditions: a fasting plasma glucose $\geq 126 \mathrm{mg} / \mathrm{dL}$, a 2-hour postload plasma glucose $\geq 200 \mathrm{mg} / \mathrm{dL}$, or a glycated hemoglobin $\geq 6.5 \%[23,24]$.

\section{Life-course SEP indicators}

Cumulative SEP scores. To study specific contributions of education level and occupational social class across the life course toward the occurrence of NODM, the following two cumulative SEP scores were created: one based on education measurements (education-based score) and one based on occupational social class indicators (occupation-based score).

The education-based score was calculated by summing up the scores for childhood SEP (maternal education assessed retrospectively: university degree $=0$, high school $=1$; complete elementary school $=2$; incomplete elementary school $=3$; never attended school $=4$ ), and adulthood SEP (participant's own education: postgraduation degree $=0$; university degree $=1$; high school $=2$; complete elementary school $=3$; incomplete elementary school $=$ 4). Thus, the education-based score ranged from 0 to 8 , with higher scores reflecting low SEP measured by education across the participants' lifespan. For analysis, this score was categorized into five groups $(0 ; 1-2 ; 3-4 ; 5-6 ; 7-8)$.

The occupation-based score was estimated using the occupational social class of the participants' own occupation and the occupation of the head of the household at the time the participant started working (assessed retrospectively). Occupational social class is a summary measure based on the following three aspects: occupation held by the individuals, the expected income based on the education level (average market value), and the observed income [25] (see Appendix A for further details). Thus, the occupation-based score was generated by summing the scores for early-life SEP (occupational social class of the household head at the time the participant started working: high $=0$, middle $=1$, low $=2$ ) and adulthood SEP (participant's own occupational social class: high $=0$, middle $=1$, low $=2$ ). Therefore, the occupation-based score ranged from 0 to 4 , with higher scores reflecting low SEP measured by their occupational social class throughout their lifespan.

Social trajectories. We investigated educational and occupational social trajectories. To derive the educational trajectory, we dichotomized maternal education values into the following two categories: high ( $\geq$ elementary school) and low (<elementary school) and the participant's own education level, high ( $\geq$ university degree) and low (<university degree). To derive occupational trajectory, we dichotomized the occupational social class of the household head as well as the participant's own occupational social 
Table 1

Descriptive characteristics of participants from the Brazilian Longitudinal Study of Adult Health (ELSA-Brasil) without previous diagnosed diabetes, $N=13,629$, 2008-2010

\begin{tabular}{|c|c|c|}
\hline Characteristics & $\begin{array}{l}\text { Men } \\
(n=6105)\end{array}$ & $\begin{array}{l}\text { Women } \\
(n=7524)\end{array}$ \\
\hline \multicolumn{3}{|l|}{ Socioeconomic position indicators } \\
\hline \multicolumn{3}{|l|}{ Maternal education, $n(\%)$} \\
\hline University degree & $422(6.9)$ & $486(6.5)$ \\
\hline High school & $1124(18.4)$ & $1237(16.4)$ \\
\hline Complete elementary school & $1140(18.7)$ & $1466(19.5)$ \\
\hline Incomplete elementary school & $2427(39.7)$ & $3249(43.2)$ \\
\hline Never attended school & $821(13.5)$ & $944(12.5)$ \\
\hline Missing & $171(2.8)$ & $142(1.9)$ \\
\hline \multicolumn{3}{|l|}{ Participants' own education, $n(\%)$} \\
\hline Postgraduation degree & $2397(39.3)$ & $2749(36.5)$ \\
\hline University degree & $762(12.5)$ & $1463(19.5)$ \\
\hline High school & $2005(32.8)$ & $2668(35.5)$ \\
\hline Complete elementary school & $494(8.1)$ & $378(5.0)$ \\
\hline Incomplete elementary school & $447(7.3)$ & $266(3.5)$ \\
\hline \multicolumn{3}{|c|}{$\begin{array}{l}\text { Occupational social class of the head of the household at the time the } \\
\text { participant started working, } n(\%)\end{array}$} \\
\hline High & $1269(20.8)$ & $1611(21.4)$ \\
\hline Middle & $1647(27.0)$ & $2075(27.6)$ \\
\hline Low & $2892(47.4)$ & $3465(46.1)$ \\
\hline Missing & $297(4.8)$ & $373(4.9)$ \\
\hline \multicolumn{3}{|c|}{ Participants' own occupational social class, $n(\%)$} \\
\hline High & $2228(36.5)$ & $2348(31.2)$ \\
\hline Middle & $2095(34.3)$ & $3559(47.3)$ \\
\hline Low & $1684(27.6)$ & $1493(19.8)$ \\
\hline Missing & $98(1.6)$ & $124(1.7)$ \\
\hline \multicolumn{3}{|c|}{ Cumulative socioeconomic position scores } \\
\hline \multicolumn{3}{|l|}{ Education-based score, $n(\%)$} \\
\hline $\begin{array}{l}0 \text { (highest education from childhood } \\
\text { to adulthood) }\end{array}$ & 349 (5.7) & $381(5.0)$ \\
\hline $1-2$ & $1458(23.9)$ & $1696(23.5)$ \\
\hline $3-4$ & $1902(31.1)$ & $2791(37.1)$ \\
\hline $5-6$ & $1701(27.9)$ & $2152(28.6)$ \\
\hline $\begin{array}{l}7-8 \text { (lowest education from } \\
\text { childhood to adulthood) }\end{array}$ & $524(8.6)$ & $362(4.8)$ \\
\hline Missing & $171(2.8)$ & $142(1.9)$ \\
\hline \multicolumn{3}{|l|}{ Occupation-based score, $n(\%)$} \\
\hline $\begin{array}{l}0 \text { (highest occupation from youth to } \\
\text { adulthood) }\end{array}$ & $854(14.0)$ & $906(12.0)$ \\
\hline 1 & $1001(16.4)$ & $1238(16.5)$ \\
\hline 2 & $1264(20.7)$ & $1792(23.8)$ \\
\hline 3 & $1389(22.7)$ & $2155(28.6)$ \\
\hline $\begin{array}{l}4 \text { (lowest occupation from youth to } \\
\text { adulthood) }\end{array}$ & 1205 (19.7) & $945(12.6)$ \\
\hline Missing & $392(6.4)$ & $488(6.5)$ \\
\hline \multicolumn{3}{|l|}{ Social trajectories } \\
\hline \multicolumn{3}{|l|}{ Education trajectory, $n(\%)$} \\
\hline High stable & $1973(32.3)$ & $2353(31.3)$ \\
\hline Upward & $1158(19.0)$ & $1835(24.4)$ \\
\hline Downward & 713 (11.7) & $836(11.1)$ \\
\hline Low stable & $2090(34.2)$ & $2358(31.3)$ \\
\hline Missing & $171(2.8)$ & $142(1.9)$ \\
\hline \multicolumn{3}{|l|}{ Occupational trajectory, $n(\%)$} \\
\hline High stable & $1828(29.9)$ & $2116(28.1)$ \\
\hline Upward & $1538(25.2)$ & $1961(26.1)$ \\
\hline Downward & $429(7.1)$ & $691(9.2)$ \\
\hline Low stable & $1918(31.4)$ & $2268(30.1)$ \\
\hline Missing & $392(6.4)$ & $488(6.5)$ \\
\hline \multicolumn{3}{|l|}{ Covariates } \\
\hline Age(years), mean (SD) & $51.5(9.2)$ & $51.5(8.7)$ \\
\hline \multicolumn{3}{|l|}{ Race, \% } \\
\hline White & $3245(53.1)$ & $3910(52.0)$ \\
\hline Brown & $1806(29.6)$ & $1989(26.4)$ \\
\hline Black & $791(13.0)$ & $1277(17.0)$ \\
\hline Other & $181(3.0)$ & $274(3.6)$ \\
\hline Missing & $82(1.3)$ & $74(1.0)$ \\
\hline \multicolumn{3}{|l|}{ Smoking, $n(\%)$} \\
\hline Never smoker & $3162(51.8)$ & $4701(62.5)$ \\
\hline Former smoker & $2065(33.8)$ & 1903 (25.3) \\
\hline Current smoker & $878(14.4)$ & $920(12.2)$ \\
\hline
\end{tabular}

Table 1 (continued)

\begin{tabular}{|c|c|c|}
\hline Characteristics & $\begin{array}{l}\text { Men } \\
(n=6105)\end{array}$ & $\begin{array}{l}\text { Women } \\
(n=7524)\end{array}$ \\
\hline \multicolumn{3}{|l|}{ Physical inactivity, $n(\%)$} \\
\hline Yes & $4276(70.0)$ & $5822(77.4)$ \\
\hline No & $1743(28.6)$ & $1590(21.1)$ \\
\hline Missing & $86(1.4)$ & $112(1.5)$ \\
\hline \multicolumn{3}{|l|}{ Hypertension, $n(\%)$} \\
\hline No & $3853(63.1)$ & $5361(71.2)$ \\
\hline Yes & $2246(36.8)$ & $2158(28.7)$ \\
\hline Missing & $6(0.1)$ & $5(0.1)$ \\
\hline $\begin{array}{l}\text { Waist circumference }(\mathrm{cm}) \text {, } \\
\text { median }(\mathrm{IQR})\end{array}$ & $94.0(86.9-101.5)$ & $85.4(78.2-94.2)$ \\
\hline Missing, $n(\%)$ & $1(0.02)$ & $1(0.01)$ \\
\hline Triglycerides (mg/dL), median (IQR) & $130(92.0-190)$ & $101.0(74-140)$ \\
\hline Missing, $n(\%)$ & $4(0.07)$ & $2(0.03)$ \\
\hline $\begin{array}{l}\text { High-density lipoprotein cholesterol } \\
(\mathrm{mg} / \mathrm{dL}) \text {, median (IQR) }\end{array}$ & $49.0(43.0-57.0)$ & $60.0(52.0-71.0)$ \\
\hline Missing, $n(\%)$ & $4(0.07)$ & $1(0.01)$ \\
\hline
\end{tabular}

class values as high (high, middle-high, middle-middle) and low (middle-low, low). Consequently, the following four potential educational and occupational trajectories were possible: highstable, upward, downward, and low-stable.

\section{Covariate assessment}

Age, self-reported race, and proximal risk factors for diabetes were used as covariates. We considered cigarette smoking (never smokers, former smokers, current smokers), physical inactivity $(<150$ minutes of moderate physical activity or $<75$ minutes of strong physical activity per week) measured by the leisure time section of the long version of the International Physical Activity Questionnaire, hypertension (systolic blood pressure $\geq 140 \mathrm{~mm} \mathrm{Hg}$ or diastolic blood pressure $\geq 90 \mathrm{~mm} \mathrm{Hg}$ or use of anti-hypertensive medication), waist circumference, triglycerides (enzymatic colorimetric assay, glycerol phosphate peroxidase-ADVIA Chemistry), and high-density lipoprotein cholesterol (HDL-c; enzymatic colorimetric assay, ADVIA Chemistry) while assessing covariates.

\section{Data analysis}

The association of each indicator in cumulative SEP and social trajectories with NODM was separately investigated using logistic regression models using complete-case analysis. After these crude analyses, we gradually added the following variables into the multivariable models: age and race (model 1); smoking and physical inactivity (model 2); waist circumference (model 3); and hypertension, HDL-c, and triglycerides (model 4).

We tested multiplicative interactions between gender and each life-course SEP indicators by including an interaction term in the fully adjusted regression models (model 4). As we found evidence for multiplicative interactions $(P<.05)$ of gender with educationbased score and occupation social trajectory, all analyses were separately conducted for men and women.

The results were presented as odds ratios (ORs) and their 95\% confidence intervals. The significance level was defined at 0.05 , and all analyses were performed with Stata 13.0 (Stata Corporation, College Station, TX, United States).

\section{Results}

The characteristics of the study population are presented in Table 1. We found 1497 (11.0\%) cases of $\operatorname{NODM}(n=823,13.5 \%$ in 

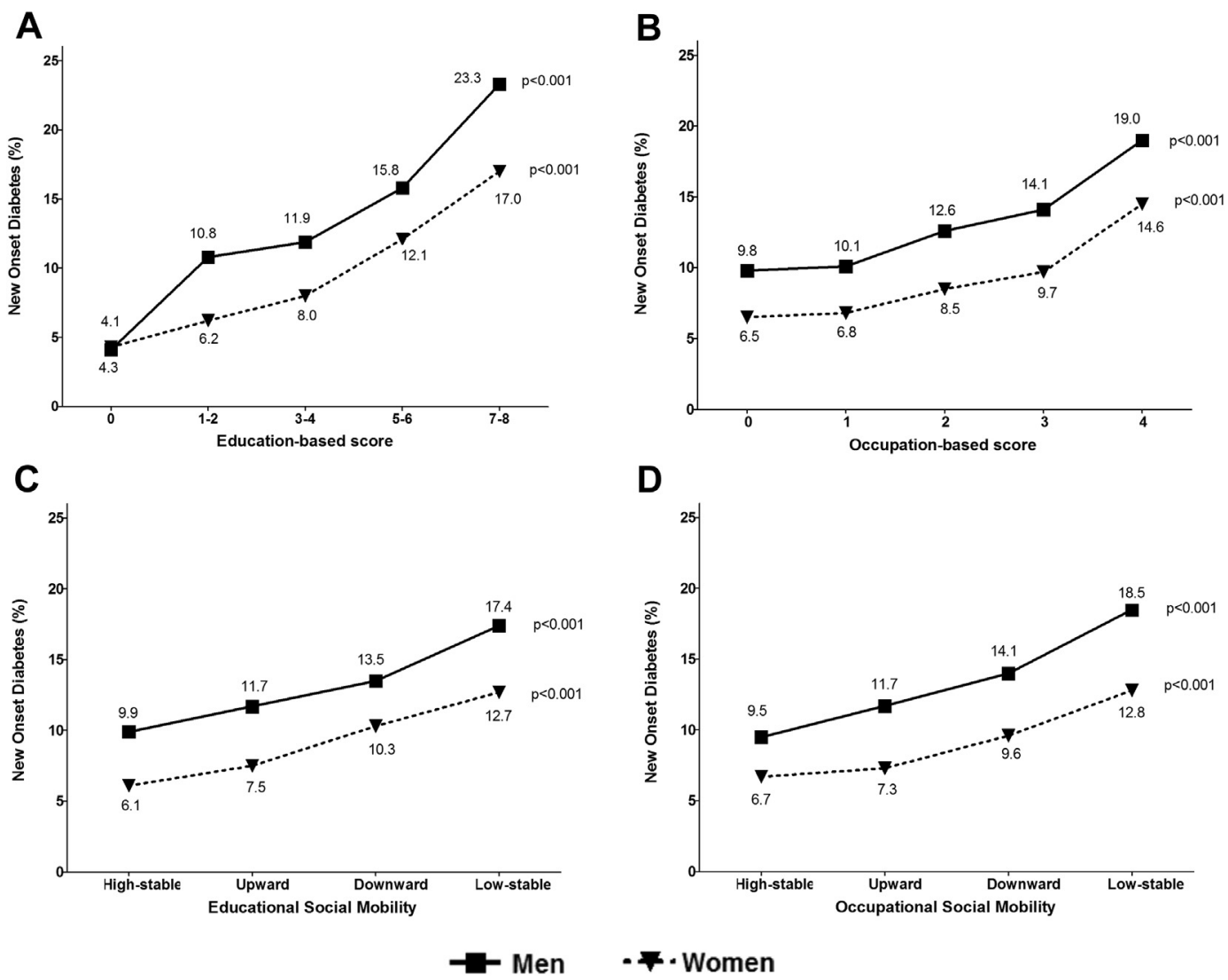

Men

\section{Women}

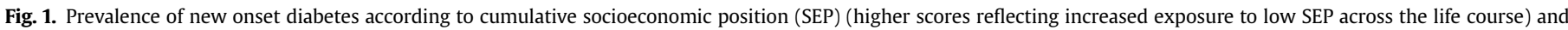

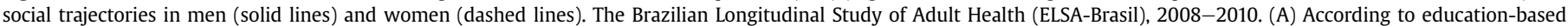

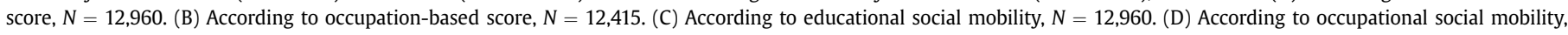
$N=12,415$.

men; $n=674,9.0 \%$ in women) who were not aware of having this condition. The crude prevalence of NODM rose with increased socioeconomic disadvantages throughout the life course, and this social gradient was more pronounced when expressed by education-based score than occupation-based score (Fig. 1), especially among men. For both genders, educational and occupational trajectories analyses showed that individuals with low-stable social trajectories presented the highest proportion of participants with NODM, followed by a downward trajectory, an upward trajectory, and then a high-stable trajectory (Fig. 1).

The analyses testing the accumulation of risk framework are presented in Table 2 . In the minimally adjusted models, we found that in general, the higher the cumulative SEP scores, the higher the odds of acquiring NODM in both genders. These associations were more pronounced in men and when the education-based scores were used. In men, the magnitude of associations did not substantially decrease after all variables were included, and in fact, the addition of waist circumference in the models resulted in an increase in the ORs (model 3). However, in women, all associations became irrelevant after adding the proximal variables.

As summarized in Table 3, comparing participants with highstable trajectories, men in upward (occupational), downward, and low-stable (educational and occupational) social trajectories presented higher odds of contracting NODM, and these associations remained statistically significant even in models with all covariates. The addition of waist circumference resulted in an increase in the magnitude of the associations in men (model 3). In women, participants with downward educational trajectory and those with low-stable trajectories (educational and occupational) presented higher odds of presenting NODM in the model with minimal covariates. However, in the models with more covariates, only low-stable educational trajectory remained associated with NODM.

\section{Discussion}

We found a marked and graded increase in the odds of NODM with increased exposure to social disadvantages throughout one's life, especially in men. After all adjustments, these associations remained statistically significant in men and remarkably high using education-based scores. Interestingly, among women, these associations disappeared after including proximal risk factors in the models, which could represent an adjustment for the mediation of the associations exerted by these risk factors. Regarding social mobility, the downward (educational and occupational) and occupational upward trajectories remained independently associated with NODM after all covariates were added in men but not in women.

Accumulation of adverse SEP was associated with NODM in a dose-response manner. Similar findings were reported in highincome countries $[4,7,8]$. We also found that the cumulative SEP scores were more predictive of diabetes when expressed through education-based scores. Additionally, this association was more pronounced in men than women, which contradicts findings in previous studies [9,11-13]. Recent meta-analysis also showed that education is consistently associated with diabetes more frequently than occupation [2], which might be because education is 
Table 2

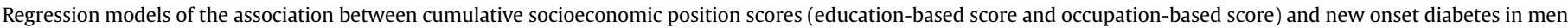
and women; the Brazilian Longitudinal Study of Adult Health (ELSA-Brasil), 2008-2010

\begin{tabular}{|c|c|c|c|c|c|}
\hline \multirow[t]{2}{*}{ Cumulative socioeconomic position scores } & \multirow{2}{*}{$\begin{array}{l}\text { Crude OR } \\
\text { OR }(95 \% \mathrm{CI})\end{array}$} & \multirow{2}{*}{$\begin{array}{l}\text { Model 1: } \\
\text { age and race } \\
\text { OR }(95 \% \mathrm{CI})\end{array}$} & \multirow{2}{*}{$\begin{array}{l}\text { Model } 2 \text { : additionally } \\
\text { adjusted for smoking } \\
\text { and physical activity } \\
\text { OR }(95 \% \mathrm{CI})\end{array}$} & \multirow{2}{*}{$\begin{array}{l}\text { Model 3: additionally } \\
\text { adjusted for waist } \\
\text { circumference } \\
\text { OR }(95 \% \mathrm{CI})\end{array}$} & \multirow{2}{*}{$\begin{array}{l}\text { Model 4: additionally, } \\
\text { adjusted for hypertension, } \\
\text { HDL-c, and triglycerides } \\
\text { OR }(95 \% \mathrm{CI})\end{array}$} \\
\hline & & & & & \\
\hline \multicolumn{6}{|l|}{ Men } \\
\hline \multicolumn{6}{|l|}{ Education-based score, $N=5763$} \\
\hline $\begin{array}{l}0 \text { (highest education in childhood } \\
\text { and adulthood) }\end{array}$ & Ref & Ref & Ref & Ref & Ref \\
\hline $1-2$ & $2.80(1.60-4.91)^{* * *}$ & $2.31(1.31-4.06)^{* *}$ & $2.28(1.30-4.02)^{* *}$ & $2.33(1.32-4.14)^{* *}$ & $2.17(1.22-3.85)^{* *}$ \\
\hline $3-4$ & $3.14(1.80-5.45)^{* * *}$ & $2.68(1.54-4.69)^{* * *}$ & $2.59(1.49-4.53)^{* *}$ & $2.82(1.60-4.98)^{* * *}$ & $2.55(1.44-4.51)^{* *}$ \\
\hline $5-6$ & $4.36(2.51-7.56)^{* * *}$ & $3.70(2.11-6.45)^{* * *}$ & $3.32(1.89-5.82)^{* * *}$ & $3.99(2.25-7.05)^{* * *}$ & $3.43(1.93-6.08)^{* * * *}$ \\
\hline $\begin{array}{l}\text { 7-8 (lowest education in childhood } \\
\text { and adulthood) }\end{array}$ & $7.02(3.96-12.46)^{* * *}$ & $4.71(2.62-8.47)^{* * *}$ & $4.09(2.27-7.37)^{* * *}$ & $5.12(2.813-9.33)^{* * *}$ & $4.45(2.44-8.13)^{* * *}$ \\
\hline \multicolumn{6}{|l|}{ Occupation-based score, $N=5552$} \\
\hline $\begin{array}{l}0 \text { (highest occupation in youth } \\
\text { and adulthood) }\end{array}$ & Ref & Ref & Ref & Ref & Ref \\
\hline 1 & $1.04(0.76-1.41)$ & $1.10(0.80-1.51)$ & $1.07(0.78-1.46)$ & $1.01(0.73-1.39)$ & $1.01(0.73-1.40)$ \\
\hline 2 & $1.33(1.00-1.77)^{*}$ & $1.44(1.08-1.93)^{*}$ & $1.38(1.03-1.85)^{*}$ & $1.37(1.02-1.85)^{*}$ & $1.33(0.98-1.80)^{*}$ \\
\hline 3 & $1.51(1.14-1.99)^{* *}$ & $1.71(1.27-2.29)^{* * *}$ & $1.56(1.16-2.10)^{* *}$ & $1.66(1.23-2.24)^{* *}$ & $1.57(1.15-2.13)^{* *}$ \\
\hline $\begin{array}{l}4 \text { (lowest occupation in youth and } \\
\text { adulthood) }\end{array}$ & $2.16(1.65-2.84)^{* * *}$ & $2.14(1.60-2.87)^{* * *}$ & $1.90(1.42-2.55)^{* * *}$ & $2.18(1.61-2.94)^{* * *}$ & $2.02(1.50-2.74)^{* * *}$ \\
\hline \multicolumn{6}{|l|}{ Women } \\
\hline \multicolumn{6}{|l|}{ Education-based score, $N=7197$} \\
\hline $\begin{array}{l}0 \text { (highest education in childhood } \\
\text { and adulthood) }\end{array}$ & Ref & Ref & Ref & Ref & Ref \\
\hline $1-2$ & $1.47(0.86-2.52)$ & $1.18(0.69-2.04)$ & $1.15(0.67-1.99)$ & $1.12(0.64-1.94)$ & $1.13(0.64-2.01)$ \\
\hline $3-4$ & $1.95(1.16-3.28)^{*}$ & $1.48(0.88-2.51)$ & $1.45(0.85-2.45)$ & $1.37(0.80-2.33)$ & $1.32(0.76-2.29)$ \\
\hline $5-6$ & $3.09(1.84-5.19)^{* * *}$ & $2.09(1.23-3.54)^{* *}$ & $1.96(1.15-3.34)^{*}$ & $1.83(1.06-3.13)^{*}$ & $1.64(0.93-2.85)$ \\
\hline $\begin{array}{l}7-8 \text { (lowest education in childhood } \\
\text { and adulthood) }\end{array}$ & $4.59(2.59-8.14)^{* * *}$ & $2.00(1.11-3.63)^{*}$ & $1.86(1.02-3.38)^{*}$ & $1.66(0.91-3.04)$ & $1.47(0.79-2.73)$ \\
\hline \multicolumn{6}{|l|}{ Occupation-based score, $N=6863$} \\
\hline $\begin{array}{l}0 \text { (highest occupation in youth and } \\
\text { adulthood) }\end{array}$ & Ref & Ref & Ref & Ref & Ref \\
\hline 1 & $1.05(0.74-1.48)$ & $1.18(0.83-1.68)$ & $1.14(0.80-1.63)$ & $1.04(0.72-1.49)$ & $0.96(0.67-1.38)$ \\
\hline 2 & $1.32(0.97-1.81)$ & $1.34(0.97-1.86)$ & $1.29(0.93-1.79)$ & $1.19(0.85-1.66)$ & $1.06(0.76-1.50)$ \\
\hline 3 & $1.54(1.14-2.09)^{* *}$ & $1.53(1.11-2.11)^{*}$ & $1.47(1.06-2.03)^{*}$ & $1.35(0.97-1.87)$ & $1.23(0.88-1.71)$ \\
\hline $\begin{array}{l}4 \text { (lowest occupation in youth } \\
\text { and adulthood) }\end{array}$ & $2.44(1.77-3.38)^{* * *}$ & $2.00(1.42-2.81)^{* * *}$ & $1.86(1.31-2.62)^{* * *}$ & $1.60(1.13-2.27)^{* * *}$ & $1.39(0.97-1.98)$ \\
\hline
\end{tabular}

Significance level: ${ }^{*}<.05,{ }^{* *}<.01,{ }^{* * *}<.001$.

associated with "health literacy," the degree to which individuals can obtain, process, and understand health information [26]. Health literacy affects the use of preventive health care and the translation of health information into habit changes that are needed to prevent diabetes. Considering that education is the most important predictor of health literacy [26-28], it is possible that the educationbased scores were more predictive of diabetes in men. This is because the same level of education can have a higher impact on health literacy in men than in women because men tend to have lower levels of health literacy than women, even independently of education $[27,28]$.

An additional reason for the stronger association between education-based scores and diabetes in men might be the use of maternal education as an indicator of early SEP. Maternal education tends to be more related with prevalence of overweight and/or obesity among children than paternal occupation and/or education [29], especially among boys [30]. As obesity is the most important proximal risk factor for diabetes, we, contrary to other studies [4,7-9,11-13], used maternal education as an indicator of early SEP. These facts might explain why our findings differ from previous studies that reported stronger associations between life-course SEP and diabetes in women [9,11-13]. Further investigations are needed to better understand this complex gender pattern.

Evaluating the social mobility model, we found that highest odds of NODM were observed among men and women in the lowstable trajectory. In women, only the educational downward trajectory was associated with increased risk of diabetes. In men, both downward (occupational and education) and upward (occupational) social trajectories were also associated with increased odds of diabetes, the former being associated stronger than the latter. Thus, it seems that low SEP in adulthood is more detrimental to one's health than in early life because the odds of NODM were greater for those who moved downward rather than upward. In addition, we observed an absence of association between educational upward trajectory and diabetes in men and women suggesting that the effect of early SEP conditions seems to be reversed if the individual achieves better SEP in adulthood. Similar findings were reported in many studies conducted in highincome countries $[4,5,9,12,13]$. Of note, changes in social hierarchy were associated with diabetes only in men in the final models, suggesting that other pathways not related to the metabolic syndrome may explain the remaining associations among men but not women.

We also found that adjustments for conventional risk factors for diabetes (especially waist circumference) highlighted gender differences. Replicating what is currently found in Brazilian population as a whole [31,32], we found, among women, that the greater the social adversity is in one's lifetime, the larger the waist circumference is, whereas men exposed to extremely high SEP across their lifespan, have a larger waist circumference than those with extremely low SEP (Table B1). Moreover, the association of hypertriglyceridemia, low HDL-c and hypertension and life-course SEP was weaker in men than in women (Table B1). This difference might explain why the addition of proximal risk factors for diabetes 
Table 3

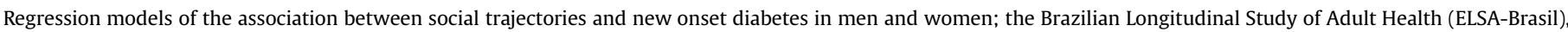
2008-2010

\begin{tabular}{|c|c|c|c|c|c|}
\hline \multirow[t]{2}{*}{ Social mobility } & \multirow{2}{*}{$\begin{array}{l}\text { Crude OR } \\
\text { OR }(95 \% \mathrm{CI})\end{array}$} & \multirow{2}{*}{$\begin{array}{l}\text { Model } 1 \text { : age } \\
\text { and race } \\
\text { OR }(95 \% \mathrm{CI})\end{array}$} & \multirow{2}{*}{$\begin{array}{l}\text { Model 2: additionally } \\
\text { adjusted for smoking } \\
\text { and physical activity } \\
\text { OR }(95 \% \mathrm{CI})\end{array}$} & \multirow{2}{*}{$\begin{array}{l}\text { Model 3: additionally } \\
\text { adjusted for waist } \\
\text { circumference } \\
\text { OR }(95 \% \mathrm{CI})\end{array}$} & \multirow{2}{*}{$\begin{array}{l}\text { Model 4: additionally } \\
\text { adjusted for hypertension } \\
\text { HDL-c, and triglycerides } \\
\text { OR }(95 \% \mathrm{CI})\end{array}$} \\
\hline & & & & & \\
\hline \multicolumn{6}{|l|}{ Men } \\
\hline \multicolumn{6}{|c|}{ Educational trajectories, $N=5763$} \\
\hline High-stable & Ref & Ref & Ref & Ref & Ref \\
\hline Upward & $1.21(0.95-1.53)$ & $1.11(0.87-1.41)$ & $1.11(0.87-1.42)$ & $1.22(0.95-1.56)$ & $1.19(0.93-1.53)$ \\
\hline Downward & $1.43(1.09-1.85)^{* *}$ & $1.58(1.20-2.08)^{* *}$ & $1.44(1.19-1.90)^{*}$ & $1.58(1.19-2.10)^{* *}$ & $1.44(1.08-1.92)^{*}$ \\
\hline Low-stable & $1.93(1.60-2.34)^{* * *}$ & $1.80(1.47-2.21)^{* * *}$ & $1.62(1.31-1.99)^{* * *}$ & $1.93(1.56-2.39)^{* * *}$ & $1.76(1.42-2.18)^{* * *}$ \\
\hline \multicolumn{6}{|c|}{ Occupational Trajectories, $N=5552$} \\
\hline High-stable & Ref & Ref & Ref & Ref & Ref \\
\hline Upward & $1.26(1.01-1.57)^{*}$ & $1.29(1.03-1.62)^{*}$ & $1.27(1.01-1.60)^{*}$ & $1.35(1.07-1.71)^{*}$ & $1.32(1.04-1.67)^{*}$ \\
\hline Downward & $1.55(1.13-2.13)^{* *}$ & $1.59(1.14-2.20)^{* *}$ & $1.43(1.03-1.99)^{*}$ & $1.53(1.09-2.14)^{* *}$ & $1.44(1.03-2.02)^{*}$ \\
\hline Low-stable & $2.14(1.76-2.61)^{* * *}$ & $2.10(1.70-2.60)^{* * *}$ & $1.93(1.55-2.39)^{* * *}$ & $2.20(1.76-2.74)^{* * *}$ & $2.06(1.65-2.58)^{* * *}$ \\
\hline \multicolumn{6}{|l|}{ Women } \\
\hline \multicolumn{6}{|c|}{ Educational trajectories, $N=7197$} \\
\hline High-stable & Ref & Ref & Ref & Ref & Ref \\
\hline Upward & $1.25(0.98-1.60)$ & $1.15(0.89-1.47)$ & $1.16(0.90-1.48)$ & $1.18(0.91-1.52)$ & $1.14(0.88-1.47)$ \\
\hline Downward & $1.78(1.34-2.36)^{* * *}$ & $1.53(1.14-2.06)^{* *}$ & $1.47(1.09-1.98)^{*}$ & $1.36(1.01-1.85)^{*}$ & $1.27(0.94-1.73)$ \\
\hline Low-stable & $2.23(1.81-2.75)^{* * *}$ & $1.71(1.36-2.15)^{* * *}$ & $1.64(1.30-2.06)^{* * *}$ & $1.57(1.24-1.98)^{* * *}$ & $1.39(1.10-1.77)^{* *}$ \\
\hline \multicolumn{6}{|c|}{ Occupational trajectories, $N=6863$} \\
\hline High-stable & Ref & Ref & Ref & Ref & Ref \\
\hline Upward & $1.09(0.86-1.40)$ & $1.09(0.85-1.41)$ & $1.08(0.84-1.39)$ & $1.06(0.82-1.37)$ & $0.99(0.77-1.29)$ \\
\hline Downward & $1.47(1.08-2.01)^{*}$ & $1.28(0.93-1.75)$ & $1.22(0.88-1.68)$ & $1.13(0.82-1.57)$ & $0.97(0.70-1.36)$ \\
\hline Low-stable & $2.04(1.65-2.52)^{* * *}$ & $1.64(1.30-2.06)^{* * *}$ & $1.57(1.24-1.98)^{* * *}$ & $1.48(1.16-1.87)^{* *}$ & $1.33(1.05-1.70)^{* *}$ \\
\hline
\end{tabular}

Significance level: ${ }^{*}<.05,{ }^{* *}<.01,{ }^{* * *}<.001$.

in models attenuates the magnitude of the association of life-course SEP with NODM mostly in women.

Investigating the social mobility framework allowed us to identify which periods of life are the most susceptible to low SEP. Because of this characteristic, Mishra et al (2009) [33] contended that the social mobility model is very similar to the "critical period model with later effect of modification" [10] (i.e., to say, that the effect of adversities that occur during critical periods in childhood can either be enhanced or diminished by future adversities) since both models assume that the health effects of low SEP early in life differ from levels of adulthood SEP. Therefore, in this analysis, we can say that the investigation of the social mobility framework improved the comprehension of the accumulation of risk model because although there is evidence that shows "how" and "when" the accumulation of risk occurs, it is important to understand the accumulation process [10], the strategy that we used to access the accumulation of risk assumed that low SEP in different periods of one's life has an equal effect on the risk of diabetes, which is a simplification of this framework.

Potential strengths of our analysis should be considered. Although this study is a cross-sectional analysis, the utilization of NODM as an outcome has minimized reversed causality because it is unlikely that an undiagnosed disease would influence SEP in a downward direction, especially early SEP. We constructed cumulative SEP scores separately for measures of education and occupation and also evaluated their trajectories separately. This strategy allowed us to evaluate the role of education and occupation across one's lifespan in the occurrence of diabetes, and our results are in agreement with the assertion that although education and occupation are correlated indicators, they capture distinct causal processes.

We also have some limitations. Both indicators of early SEP used in this article were obtained retrospectively, which may bring inaccuracies. However, if this error is nondifferential, the association of cumulative SEP scores and social trajectories with diabetes might be underestimated. Many studies have used participants' education as a youth SEP indicator because education is generally complete in late adolescence. However, we used the participants' education as an indicator of adulthood SEP because almost $40 \%$ of ELSA-Brasil participants have a postgraduate degree indicating that education was finished in the later stages of life. Our sample consisted of employees from universities and research institutes. Because people who experienced extreme social adversities as well as people at the top of the social hierarchy are not well represented in this study, the magnitude of the associations between life-course SEP and NODM is likely to underestimate in this study. This limitation can be addressed by an additional analysis based on representative population samples.

\section{Conclusion}

In summary, increased exposure to social disadvantages throughout one's life was associated with NODM, especially in men and when cumulative SEP was evaluated by educational indicators. In the social mobility analysis, we identified that low SEP in adulthood appears to be more relevant to diabetes occurrence than low SEP in early life. In women, changes in social hierarchy and accumulated exposure to social adversities do not seem to have an impact on the risk of diabetes once the variables related to the metabolic syndrome have been taken into account, suggesting differences in mechanisms connecting life-course SEP and diabetes in men and women. Finally, our findings support the hypothesis that the accumulation of risk and social mobility frameworks should not be considered competitive theories of disease causation, as the examination of social mobility helps our understanding of the accumulation of the risk framework

\section{Acknowledgments}

The authors would like to thank all ELSA-Brasil participants for their valuable contribution to this study. This work was supported by the Brazilian Ministry of Health (Department of Science and Technology) and the Ministry of Science, Technology and Innovation (FINEP, Financiadora de Estudos e Projetos and CNPq, National Research Council), grants 0106 0010.00, 0106 0212.00, 0106 
0300.00, 0106 0278.00, 0106 0115.00, and 0106 0071.00. L.V.C. was supported by a postdoctoral research fellow of Coordination of Higher Education Personnel Improvement (CAPES). S.M.B. (CNPq, grant 300159/99-4) and L.G. (CNPq, grant 312371/2013-6), B.B.D. (CNPq, grant 308521/2010-2), M.I.S. (CNPq, grant 305489/2011-9), R.H.G. (CNPq, grant 303251/2013-1), and D.C. (CNPq, grant 303371/ 2014-5) are research fellow of the National Research Council (CNPq, Brasília, Brazil).

\section{References}

[1] Vos T, Barber RM, Bell B, Bertozzi-Villa A, Biryukov S, Bolliger I. Global, regional, and national incidence, prevalence, and years lived with disability for 301 acute and chronic diseases and injuries in 188 countries, 1990-2013: a systematic analysis for the Global Burden of Disease Study 2013. Lancet 2015;386(9995):743-800.

[2] Agardh E, Allebeck P, Hallqvist J, Moradi T, Sidorchuk A. Type 2 diabetes incidence and socio-economic position: a systematic review and meta-analysis. Int J Epidemiol 2011;40(3):804-18.

[3] Tamayo T, Jacobs Jr DR, Strassburger K, Giani G, Seeman TE, Matthews K, et al. Race- and sex-specific associations of parental education with insulin resistance in middle-aged participants: the CARDIA study. Eur J Epidemiol 2012;27(5):349-55.

[4] Stringhini S, Batty GD, Bovet P, Shipley MJ, Marmot MG, Kumari M, et al. Association of lifecourse socioeconomic status with chronic inflammation and type 2 diabetes risk: the Whitehall II prospective cohort study. PLoS Med 2013;10(7):e1001479.

[5] Lidfeldt J, Li TY, Hu FB, Manson JE, Kawachi I. A prospective study of childhood and adult socioeconomic status and incidence of type 2 diabetes in women. Am J Epidemiol 2007;165(8):882-9.

[6] Lawlor DA, Steme JA, Tynelius P, Davey Smith G, Rasmussen F. Associations of childhood socioeconomic position with cause specific mortality in a prospective record linkage study of 1,839,384 individuals. Am J Epidemiol 2006;164(9):907-15.

[7] Lawlor DA, Patel R, Fraser A, Smith GD, Ebrahim S. The association of lifecourse socioeconomic position with diagnosis, treatment, control and survival of women with diabetes: findings from the British Women's Heart and Health Study. Diabet Med 2007;24(8):892-900.

[8] Langenberg C, Araneta MR, Bergstrom J, Marmot M, Barrett-Connor E. Diabetes and coronary heart disease in Filipino-American women: role of growth and life-course socioeconomic factors. Diabetes Care 2007;30 (3):535-41.

[9] Smith BT, Lynch JW, Fox CS, Harper S, Abrahamowicz M, Almeida ND, et al. Lifecourse socioeconomic position and type 2 diabetes mellitus: The Framingham Offspring Study. Am J Epidemiol 2011;173:438-47.

[10] Ben-Shlomo Y, Kuh D. A life course approach to chronic disease epidemiology: conceptual models, empirical challenges and interdisciplinary perspectives. Int J Epidemiol 2002;31(2):285-93.

[11] Ko MJ, Kim MK. The relationship between high blood glucose and socioeconomic position in childhood and adulthood in Korea: findings from the Korean National Health and Nutrition Examination, 2007-09. Int J Epidemiol 2012;41(3):733-42.

[12] Regidor E, Banegas JR, Gutiérrez-Fisac JL, Domínguez V, Rodríguez-Artalejo F. Socioeconomic position in childhood and cardiovascular risk factors in older Spanish people. Int J Epidemiol 2004;33(4):723-30.

[13] Insaf TZ, Srogatz DS, Yucel RM, Chasan-Taber L, Shaw BA. Associations between race, lifecourse socioeconomic position and prevalence of diabetes among US women and men: results from a population-bases panel study. J Epidemiol Community Health 2014;68(4):318-25.

[14] Hallqvist J, Lynch J, Bartley M, Lang T, Blane D. Can we disentangle lifecourse processes of accumulation, critical period and social mobility? An analysis of disadvantaged socio-economic positions and myocardial infarction in the Stockholm Heart Epidemiology Program. Soc Sci Med 2004:58(8):1555-62.

[15] Ferreira FHG, Messina J, Rigolini J, López-Calva LF, Lugo MA, Vakis R, et al Economic mobility and the rise of the Latin American middle class. World Bank Latin American and Caribbean studies, Washington DC; 2013.

[16] UNESCO. Progress of literacy in various countries-A preliminary statistical study of available census data since 1900, Paris. 1953. Available at: http:// unesdoc.unesco.org/images/0000/000028/002898EB.pdf [accessed 02.11.2016].

[17] Instituto Brasileiro de Geografia e Estatistica. Pesquisa nacional por amostra de domicílios : síntese de indicadores 2013/IBGE, Coordenação de Trabalho e Rendimento. 2nd ed. Rio de Janeiro: IBGE; 2015. p. 296.

[18] Ribeiro CAC. Quatro Décadas de Mobilidade Social no Brasil. Revista de Ciências Sociais 2012;55(3):641-79.

[19] Organization for Economic Cooperation and Development. Social and Welfare Issues. Inequallity. Available at: http://www.oecd.org/social/inequality.htm [accessed 07.08.2016].

[20] Hertz T, Jayasundera T, Piraino P, Selcuk S, Smith N. The inheritance of educational inequality: international comparisons and fifty-year trends. B E J Econ Anal Policy 2007;7(2):1-46.

[21] Aquino EM, Barreto SM, Bensenor IM, Carvalho MS, Chor D, Duncan BB, et al ELSA-Brazil (Brazilian Longitudinal Study of Adult Health): objectives and design. Am J Epidemiol 2012;175(4):315-24.

[22] Schmidt MI, Duncan BB, Mill JG, Lotufo PA, Chor D, Barreto SM, et al. Cohort profile: Longitudinal Study of Adult Health (ELSA-Brasil). Int J Epidemiol 2015;44(1):68-75.

[23] WHO. Definition and diagnosis of diabetes mellitus and intermediate hyperglycaemia. Geneva (Switzerland): WHO; 2006.

[24] WHO. Use of glycated haemoglobin (HbA1c) in the diagnosis of diabetes mellitus. Geneva (Switzerland): WHO; 2011.

[25] Camelo LV, Giatti L, Chor D, Griep RH, Benseñor IM, Santos IS, et al. Associations of life-course socioeconomic position and job stress with carotid intima-media thickness. The Brazilian Longitudinal Study of Adult Health (ELSA-Brasil). Soc Sci Med 2015;141:91-9.

[26] Berkman ND, Davis TC, McCormack L. Health literacy: what is it? J Health Commun 2010;15(Suppl 2):9-19.

[27] Martin LT, Ruder T, Escarce JJ, Ghosh-Dastidar B, Sherman D, Elliott M, et al Developing predictive models of health literacy. J Gen Intern Med 2009;24(11):1211-6.

[28] Jeppesen KM, Coyle JD, Miser WF. Screening questions to predict limited health literacy: a cross-sectional study of patients with diabetes mellitus. Ann Fam Med 2009;7(1):24-31.

[29] Shrewsbury V, Wardle J. Socioeconomic status and adiposity in childhood: a systematic review of cross-sectional studies 1990-2005. Obesity (Silver Spring) 2008;16(2):275-84.

[30] van Vliet JS, Gustafsson PA, Duchen K, Nelson N. Social inequality and agespecific sex differences in overweight and perception of overweight among Swedish children and adolescents: a cross-sectional study. BMC Public Health 2015;15:628.

[31] Monteiro CA, Conde WL, Popkin BM. Income-specific trends in obesity in Brazil: 1975-2003. Am J Public Health 2007:97(10):1808-12.

[32] Malta DC, da Silva SA, de Oliveira PP, Iser BP, Bernal RT, Sardinha LM, et al. Monitoring of risk and protective factors for chronic non communicable diseases by telephone survey in Brazilian State Capitals, 2008. Rev Bras Epidemiol 2012:15(3):639-50.

[33] Mishra G, Nitsch D, Black S, De Stavola B, Kuh D, Hardy R. A structured approach to modelling the effects of binary exposure variables over the lifecourse. Int J Epidemiol 2009;38(2):528-37. 


\section{Appendix A}

\section{Classifying occupations in ELSA-Brasil}

Participants' occupations were obtained by the following openended question: "Please, describe the main tasks you perform in your work." The occupation of the head of the household, at the time the participant started working, was measured by the following open-ended question: "What was the main occupation or activity of the head of the household or the main provider for your household at the time you started working?" Using this information, the occupation of the participant and the occupation of the head of the household were classified according to the Brazilian Classification of Occupations, a document that normalizes, recognizes, names, describes, and encodes occupational titles. (Brasil. Ministério do Trabalho e Emprego. CBO-Classificação Brasileira das Ocupações. Available at: http://www.mtecbo.gov.br/cbosite/pages/ home.jsf.)

Obtaining occupational social classes in ELSA-Brasil cohort

The occupational social class of the participants' occupation was obtained using information about the participants' occupation, education, and income through the following four steps:

- Step 1: Estimation of the expected income of individuals with the same level of education using a function of educationincome (average market value).
- Step 2: The socioeconomic status was estimated using the mean value of the expected income (obtained in the previous step) and the observed income for each participant.

- Step 3: For each occupational title, the mean score of the socioeconomic status of individuals was calculated to obtain the occupational socioeconomic status.

- Step 4: Using these occupational socioeconomic status scores, strata grouping was defined to achieve a minimum intrastratum variance of the values of the scores and a maximum variation between the strata. Thus, these scores were categorized into 7 levels (high-upper, high-low, middle-upper, middle-middle, middle-low, low-high, and low-low). These categorized variables were named for the occupational social class of the participants' occupation.

The occupational socioeconomic status obtained in step 3 was also used to classify the occupational titles of the head of the household to obtain the occupational social class of the head of the household at the time the participant started working.

In this article, both measures of occupational social class were summarized as the following three categories: high (high-upper and high-low), middle (middle-upper, middle-middle and middlelow), and low (low-high and low-low).

\section{Appendix B}

Appendix Table B1 Distribution of proximal diabetes risk factors according to education-based score in men and women; The Brazilian Longitudinal Study of Adult Health (ELSA-Brasil), $N=12,518$, 2008-2010

Appendix Table B1

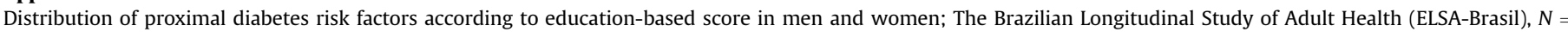
12,518, 2008-2010

\begin{tabular}{|c|c|c|c|c|c|c|}
\hline \multirow[t]{2}{*}{ Covariates } & \multicolumn{6}{|c|}{ Education-based score } \\
\hline & 0 , highest SEP & $1-2$ & $3-4$ & $5-6$ & $7-8$, lowest SEP & $P$ for trend \\
\hline \multicolumn{7}{|l|}{ Men } \\
\hline Smoking, \% & 11.5 & 9.5 & 12.8 & 17.3 & 22.5 & $<.001$ \\
\hline Physical inactivity, \% & 61.2 & 65.2 & 67.7 & 77.0 & 83.8 & $<.001$ \\
\hline Hypertension, \% & 25.1 & 34.0 & 33.4 & 40.0 & 51.3 & $<.001$ \\
\hline Waist circumference $(\mathrm{cm})$, median & 94.4 & 95.1 & 94.0 & 93.0 & 93.5 & $<.001$ \\
\hline Triglycerides (mg/dL), median & 118.0 & 127.0 & 128.0 & 135.0 & 128 & $<.001$ \\
\hline HDL-c (mg/dL), median & 50.0 & 49.0 & 50.0 & 48.0 & 50.0 & .228 \\
\hline \multicolumn{7}{|l|}{ Women } \\
\hline Smoking, \% & 9.3 & 10.1 & 10.9 & 14.6 & 17.0 & $<.001$ \\
\hline Physical inactivity, \% & 59.7 & 70.1 & 78.1 & 86.6 & 90.9 & $<.001$ \\
\hline Hypertension, \% & 15.2 & 21.3 & 26.8 & 34.7 & 52.4 & $<.001$ \\
\hline Waist circumference $(\mathrm{cm})$, median & 82.0 & 84.0 & 85.1 & 86.9 & 90.7 & $<.001$ \\
\hline Triglycerides (mg/dL), median & 91.0 & 96.0 & 101.0 & 105.0 & 115.0 & $<.001$ \\
\hline HDL-c (mg/dL), median & 65.0 & 62.0 & 60.0 & 58.0 & 59.0 & $<.001$ \\
\hline
\end{tabular}

